\title{
Standardized ileal digestibility of amino acids of protein sources associated with exogenous enzymes for broilers
}

\author{
Bruno Duarte Alves Fortes ${ }^{1, \star}$, Heloisa Helena de Carvalho Mello ${ }^{2}$, Marcos Barcellos Café2, \\ Emmanuel Arnhold ${ }^{2}$, and José Henrique Stringhini ${ }^{2}$
}

\begin{abstract}
* Corresponding Author:
Bruno Duarte Alves Forte

Tel: +55-62-98400-0900,

E-mail: bruno.fortes@ifgoiano.edu.br

${ }^{1}$ Federal Institute of Education, Science and Technology Goiano, Iporá, 76200-000, Brazil

2 Department of Animal Science, Federal

University of Goiás, Goiás, 74690-900, Brazi

ORCID

Bruno Duarte Alves Fortes

https://orcid.org/0000-0002-4493-8522

Heloisa Helena de Carvalho Mello

https://orcid.org/0000-0002-0312-7424

Marcos Barcellos Café

https://orcid.org/0000-0002-1478-8009

Emmanuel Arnhold

https://orcid.org/0000-0003-0922-146X

José Henrique Stringhini

https://orcid.org/0000-0002-3710-6963
\end{abstract}

Submitted Sept 11, 2021; Revised Oct 27, 2021; Accepted Dec 12, 2021
Objective: Two experiments were conducted to evaluate the effect of enzyme complex (EC) on the standardized ileal digestibility (SID) of amino acids (AA) in corn gluten meal (60\%) (CGM), soy protein concentrate (SPC), dried bovine plasma (DBP), and poultry offal meal (POM). Experiments I and II were conducted with broilers in the pre-starter (1 to 7 days of age) and starter ( 1 to 21 days of age) phases, respectively.

Methods: The treatments consisted of a protein-free diet (PFD) containing feedstuffs either supplemented with EC (xylanase, amylase, and protease) or not. In Experiment I, a total of 360 one-day-old male Cobb-500 broiler chicks were randomly housed in 45 pens, resulting in five replicates with eight birds each, totalizing eight treatments and one PFD group. In Experiment II a total of 270 one-day-old male Cobb-500 broiler chicks were randomly housed in 45 pens, resulting in five replicates with six birds each, totalizing eight treatments and one PFD group. The PFD groups were used to assess the endogenous AA losses. The birds were slaughtered to collect the ileal content.

Results: In the pre-starter phase, the SID of arginine, branched chain-aminoacids, glycine, serine, aspartate, and glutamic acid increased with EC addition. The EC improved the SID of arginine and glutamic acid of CGM; the SID of valine and cystine of SPC; the SID of leucine, glycine, and aspartate of POM and the SID of isoleucine of DBP. In the starter phase, the SID of isoleucine, phenylalanine and glycine increased in EC-supplemented diets. The EC improved the SID of isoleucine of DBP; the SID of phenylalanine of CGM and POM. The SID of AA of SPC was not influenced by the EC.

Conclusion: The addition of an EC to broiler pre-starter and starter diets is efficient in increasing the SID of AA on SPC, POM, and DBP.

Keywords: Enzyme Complex; Feedstuffs; Multivariate Analysis; Poultry

\section{INTRODUCTION}

Alternative ingredients to corn and soybean meal have been used in broiler diets in the poultry industry; however, knowledge of the AA digestibility of these foods is a concern among nutritionists. Several factors are believed to affect AA digestibility, such as the bioassay and animal age [1], ingredient origin [2], the timing of planting and harvesting [3], a fermentation process of the ingredients [4] and exogenous enzyme complex (EC) $[5,6]$.

The use of enzymes in their mono-component form or combined in blends is routine practice in poultry feeding. The efficacy of exogenous protease on AA digestibility in broiler diets that contain both xylanase and phytase was verified by [6]. Xylanase is effective to improve the ileal amino acid (AA) digestibility in broiler chickens [7]. Enzyme complexes such as xylanase, amylase and protease may be used in broilers' diets, aiming to increase their performance and nutrient digestibility [8]. This better performance can be attributed to an enhancement of nutrient digestibility, including AA digestibility. 
Different effects of the enzyme are observed according to the developmental stages of the birds. In young broilers, this is even more significant, since major differences in physiological development will impact their development throughout life $[9,10]$. In addition, it has been reported that bird age per $s e$ is a factor that affects AA digestibility of ingredients [1]. For this reason, the quality of ingredients and meeting the requirement of AAs for broilers in the pre-starter and starter phases of life is important to ensure their slaughter weight.

The main protein source for broilers is soybean meal. However, to reduce the diet costs, alternative by-products and an EC can be used. It was demonstrated that a multicarbohydrase and phytase complex allows a saving in feed cost while guaranteeing the same performance of the broilers [11]. Corn gluten meal, soy protein concentrate (SPC), dried bovine plasma (DBP) and poultry offal meal (POM) provide a higher protein content and are commonly used in non-ruminant diets. The dietary AAs affect the body weight gain, the growth rate, the feed conversion ratio, the internal organ development [12], and the function of the gastrointestinal tract of broilers [13]. Therefore, the EC is used in diets to improve the digestibility of the AAs in by-products. Some authors concluded that feeding a combination of multicarbohydrase and phytase results in higher standardized ileal digestibility (SID) of arginine, histidine, methionine, and threonine relative to a single activity in canola meal [14].

The present study was conducted to evaluate the effect of EC on the SID of AAs in CGM (60\%), SPC, DBP, and POM to broiler pre-starter and starter diets.

\section{MATERIALS AND METHODS}

\section{Animal care and study site}

The experiments were conducted on the poultry facilities at the Department of Animal Science of the Federal University of Goiás (UFG), Brazil. Experimental protocols received approval from the Ethics Committee on Animal Use of UFG (case no. 066/12).

\section{Animals, experimental design}

Two experiments were carried out to assess the SID of AA in CGM (60\%), SPC, DBP, and POM with an EC or not, for broilers in the pre-starter (1 to 7 days of age, Experiment I) and starter phase (1 to 21 days of age, Experiment II).

In both experiments, a group of broilers were fed a protein-free diet (PFD) to assess the endogenous losses of AAs and calculate the SID of AAs.

In Experiment I, a total of 360 one-day-old male Cobb500 broiler chicks from a commercial hatchery were randomly housed in 45 pens, resulting in five replicates with eight birds each in the pre-starter phase, totalizing eight treatments and one PFD group.

In Experiment II a total of 270 one-day-old male Cobb500 broiler chicks from a commercial hatchery were randomly housed in 45 pens, resulting in five replicates with six birds each in the starter phase, totalizing eight treatments and one PFD group.

\section{Experimental diets}

The experimental diets included four protein sources: CGM, SPC, DBP, and POM, which were each supplemented with EC or not, totalizing eight treatments.

The experimental diets were made with the inclusion of feedstuff to replace the cornstarch of PFD. CGM and SPC replaced $20 \%$ of the cornstarch in the diet. DBP and POM replaced $17 \%$ of the cornstarch in the diet (Table 1). The EC (Axtra) contained (per kg) 2,000 U xylanase, $200 \mathrm{U}$ amylase and 4,000 U protease. Enzyme addition followed the manufacturer recommendations. The acid-insoluble ash Celite was included at $1 \%$ as an indigestible marker for calculating standardized AA digestibility [15]. The birds were allowed a period of five days of adaptation to the experimental diets. Water and feed were available ad libitum throughout the experimental period.

The dry matter (DM), crude protein $(\mathrm{CP})$ contents and the total AA composition of the analyzed feedstuffs are described in Table 2.

\section{Broiler management}

From one to seven (Experiment I) and one to 21 days of age (Experiment II), the chicks were raised in five broiler battery galvanized steel cages equipped with trough-type feeders and drinkers. Each battery contained five floors with $0.33 \times 0.50$ $\mathrm{m}$ divisions. To heat the birds, 40-watt incandescent lamps were used for each battery floor until the birds completed 7 and 14 days of age, in Experiments I and II, respectively. The broilers were managed according to the management guidelines of the line. Ambient temperature and relative humidity were recorded daily, and adequate curtain management was adopted.

\section{Ileal content sample collection}

At seven (Experiment I) and 21 (Experiment II) days of age, all birds from all replicates were slaughtered by cervical dislocation and immediately dissected at $5 \mathrm{~cm}$ from the ileocecalcolic junction to $40 \mathrm{~cm}$ towards the jejunum for ileal content collection and determination of endogenous AA losses, following Sakomura and Rostagno [15] recommendations.

The ileal content was packed in plastic bags, labelled, and stored in a freezer at $-16^{\circ} \mathrm{C}$. Samples of ingredients, diets and ileal contents were vacuum-freeze-dried at a temperature of $-40^{\circ} \mathrm{C}$ for 72 hours and sent to the Animal Nutrition Laboratory at EVZ/UFG for processing and analysis of the DM 
Table 1. Ingredient composition of the experimental diets fed to broilers, as fed-basis (\%) (Experiment I and II)

\begin{tabular}{|c|c|c|c|c|c|c|c|c|c|}
\hline Ingredient & PFD & CGM & CGM+EC & SPC & SPC+EC & POM & POM+EC & DBP & DBP+EC \\
\hline Starch & 81.0 & 61.0 & 60.95 & 61.0 & 60.95 & 64.0 & 63.95 & 64.0 & 63.95 \\
\hline Corn gluten meal, 60\% & - & 20.0 & 20.00 & - & - & - & - & - & - \\
\hline Offal meal & - & - & - & - & - & 17.0 & 17.0 & - & - \\
\hline Dried bovine plasma & - & - & - & - & - & - & - & 17.0 & 17.0 \\
\hline Soybean oil & 4.00 & 4.00 & 4.00 & 4.00 & 4.00 & 4.00 & 4.00 & 4.00 & 4.00 \\
\hline Limestone & 0.70 & 0.70 & 0.70 & 0.70 & 0.70 & 0.70 & 0.70 & 0.70 & 0.70 \\
\hline Common salt & 0.60 & 0.60 & 0.60 & 0.60 & 0.60 & 0.60 & 0.60 & 0.60 & 0.60 \\
\hline Sugar & 5.00 & 5.00 & 5.00 & 5.00 & 5.00 & 5.00 & 5.00 & 5.00 & 5.00 \\
\hline Vitamin-mineral supplement ${ }^{1)}$ & 0.04 & 0.04 & 0.04 & 0.04 & 0.04 & 0.04 & 0.04 & 0.04 & 0.04 \\
\hline Enzyme complex²) & - & - & 0.05 & - & 0.05 & - & 0.05 & - & 0.05 \\
\hline Antioxidant ${ }^{3)}$ & 0.01 & 0.01 & 0.01 & 0.01 & 0.01 & 0.01 & 0.01 & 0.01 & 0.01 \\
\hline
\end{tabular}

PFD, diet protein free; CGM, corn gluten meal; EC, enzyme complex; SPC, soy protein concentrate; POM, poultry offal meal; DBP, dried bovine plasma.

1) Provides per kilogram of product: folic acid $200 \mathrm{mg}$, pantothenic acid $3,120 \mathrm{mg}$, biotin $10 \mathrm{mg}$, copper 1,997 mg, choline $78.10 \mathrm{~g}$, enramycin $2,000 \mathrm{mg}$, iron $11.25 \mathrm{~g}$, iodine $187.47 \mathrm{mg}$, maduramicin $937.50 \mathrm{mg}$, manganese $18.74 \mathrm{~g}$, niacin $8,400 \mathrm{mg}$, nicarbazin $10 \mathrm{~g}$, selenium $75 \mathrm{mg}$, vitamin A $1,680,000 \mathrm{IU}$, vitamin $B_{1} 436.50 \mathrm{mg}$, vitamin $B_{12} 2,400 \mathrm{mcg}$, vitamin $B_{2} 1,200 \mathrm{mg}$, vitamin $B_{6} 624 \mathrm{mg}$, vitamin $D_{3} 400,000 \mathrm{IU}$, vitamin E 3,500 IU, vitamin $\mathrm{K}_{3} 360 \mathrm{mg}$, zinc $17.50 \mathrm{~g}$.

${ }^{2)} \mathrm{Axtra}\left({ }^{3} .{ }^{3)} \mathrm{BHT}\right.$ (butylated hydroxytoluene). ${ }^{4)}$ Rice husk. ${ }^{5)}$ Celite (ash insoluble in acid).

and CP contents of feedstuffs and ileal content. The DM content was determined by drying in an oven $\left(105^{\circ} \mathrm{C}\right)$, the $\mathrm{CP}$

Table 2. Dry matter, crude protein contents and total amino acid composition of different feedstuffs for broiler, expressed in percentage (as-fed basis) $)^{1)}$

\begin{tabular}{lcccc}
\hline Items & CGM & SPC & POM & DBP \\
\hline Dry matter & 91.62 & 94.03 & 95.01 & 92.08 \\
Crude protein & 62.09 & 62.36 & 63.73 & 70.30 \\
Indispensable AA & & & & \\
$\quad$ Lysine & 1.01 & 3.81 & 4.14 & 6.86 \\
$\quad$ Methionine & 1.47 & 0.84 & 1.39 & 0.81 \\
Methionine+cystine & 2.58 & 1.73 & 2.05 & 3.68 \\
Threonine & 2.07 & 2.52 & 2.51 & 4.95 \\
Arginine & 1.97 & 4.55 & 4.16 & 4.01 \\
Histidine & 1.33 & 1.60 & 1.06 & 2.88 \\
Valine & 2.83 & 2.80 & 2.93 & 4.96 \\
Isoleucine & 2.51 & 2.74 & 2.42 & 2.35 \\
Leucine & 10.23 & 4.85 & 4.48 & 7.21 \\
Phenylalanine & 3.90 & 3.20 & 2.51 & 4.41 \\
Glycine & 1.49 & 2.64 & 4.74 & 2.98 \\
Dispensable AA & & & & \\
Cystine & 1.10 & 0.89 & 0.67 & 2.17 \\
Alanine & 5.51 & 2.72 & 3.34 & 4.02 \\
Aspartic acid & 3.77 & 7.25 & 4.49 & 8.12 \\
Glutamic acid & 13.59 & 11.28 & 7.02 & 11.79 \\
Serine & 3.12 & 3.34 & 4.60 & 4.98 \\
Proline & 1.56 & 3.04 & 4.65 & 4.11 \\
\hline Aminogramdevelo & & & & \\
\hline
\end{tabular}

1) Aminogram developed by Evonik Industries AG Feed Additives/Animal Nutrition Services.

CGM, corn gluten meal; SPC, soy protein concentrate; POM, poultry offal meal; DBP, dried bovine plasma; AA, amino acid. by the micro-Kjeldahl method (nitrogen distiller Tecnal TE0364; Tecnal Industry Trade Import and Export of Scientific Laboratory Equipment, Piracicaba, SP, Brazil). The analysis was determined according to the procedures described by Silva and Queiroz [16]. To determine the total AA content, high performance/pressure liquid chromatography was performed at the Laboratory of Evonik Industries (Hanau, Germany).

\section{Calculations}

The SID of AAs was calculated according to the proposal equations from Sakomura and Rostagno [15], as follow:

$$
\begin{aligned}
& \text { AID (\%) }=[(\text { Aadiet }[\mathrm{DM}, \%] / \text { AIAdiet [\%] }) \\
& \text { - (AA ileal digesta [\%]/AIA ileal digesta [\%])] } \\
& \times 100 / \text { AA diet (DM, \%)/AIAdiet (\%) }
\end{aligned}
$$

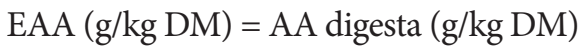

$$
\begin{aligned}
& \times \text { [AIA diet }(\mathrm{g} / \mathrm{kg} \mathrm{DM}) \\
& \text { /AIA digesta (g/kg DM)] } \\
& \operatorname{SID}(\%)=\operatorname{AID}(\%)+[\mathrm{EAA}(\mathrm{g} / \mathrm{kg} \mathrm{DM}) \\
& \text { /AA diet (g/kg DM)]×100 }
\end{aligned}
$$

in which: AID, apparent ileal digestibility of the AA; AIA, acid-insoluble ash; SID, standardized ileal digestibility of AA; DM, dry matter; EAA, basal endogenous AA loss.

The standardized AA content of feedstuffs was calculated according to the total AA content and the SID and presented 
as a fed basis.

\section{Statistical analysis}

The data were subjected to analysis of variance, and to mean comparison by the Scott Knott test at the 5\% significance level, using the R statistical program, R Core Team 2021. The statistical model included the fixed effects of feedstuffs and EC supplementation, and their interaction effect, and the random effects of the experimental unit. Data were analyzed within each feedstuff by analysis of variance to test the effects of EC within each ingredient. A multivariate analysis of principal components was performed to assess the interrelationships between variables and treatments.

\section{RESULTS}

The SID of AA in CGM (60\%), SPC, DBP, and POM, determined with broilers at seven days of age, are described in Table 3. There were verified differences in SID of all AA according to the feedstuffs. The SPC presents a higher SID of AA. However, the SID of lysine, methionine, histidine, alanine, and aspartate were similar between the CPS and the DPB. The CGM presents the lowest SID of methionine, methionine plus cystine, threonine, arginine, histidine, leucine, phenylalanine, serine, alanine, and glutamic acid. The SID of arginine, branched chain-aminoacids, glycine, serine, aspartate, and glutamic acid increased with EC addition (Table 3).

The SID of AA within each feedstuff with or without EC in pre-starter diets is shown in Table 4. The SID of arginine and glutamic acid of CGM increased with EC addition. It was observed that the SID of valine and cystine of SPC were higher with EC inclusion. The POM presented a higher SID of leucine, glycine, and aspartate when the EC was used. The SID of isoleucine of DBP increased with EC inclusion.
The SID of AA in feedstuffs determined with broilers at 21 days of age is described in Table 5. It was observed, unlike what occurred in seven days old, that the SID of some AA of SPC, DBP and CGM were similar (methionine, cystine, methionine plus cystine, threonine, valine, serine, proline, glutamic acid), indicating better utilization of AAs of alternative feedstuffs with increased age. Furthermore, the lowest SID of indispensable AA in POM was verified. The SID of isoleucine, phenylalanine and glycine increased with EC addition in the broiler starter diet (Table 5).

The SID of AAs (\%) of each feedstuff with or without EC on starter diets of broilers is described in Table 6. The EC improved the SID of phenylalanine of CGM. The SID of AA of SPC was not influenced by the EC in diets. The DBP presents a higher SID of isoleucine when the EC was used.

The standardized AA contents of the analyzed feedstuffs are described in Table 7. Although the feedstuffs studied are protein sources, the contents of AA in each presented great variation.

The results of multivariate analysis are presented in Figure 1 and 2 of the pre-starter and starter phases, respectively. It was observed that the SID of AA of SPC with or without an EC was higher than the SID of AA of CGM, DBP and POM at the pre-starter and starter phases. In the pre-starter phase, we verified that the CGM shows the lowest SID of AA, however, at the starter phase the POM shows the lowest SID of AA (Figure 1). There was no negative correlation between the SID of AA to feedstuffs studied, but there was a clear positive correlation between the SID of some AA studied, such as proline and serine in the pre-starter phase. At the starter phase, the SID of phenylalanine, isoleucine and cystine showed no correlation (Figure 2).

Table 3. Standardized ileal digestibility of amino acids (\%) of feedstuffs determined in seven-day-old broilers

\begin{tabular}{|c|c|c|c|c|c|c|c|c|c|c|c|c|c|c|c|c|c|}
\hline Items & Lys & Met & Cys & $M+C$ & Thr & Arg & His & Val & Iso & Leu & Phe & Gly & Ser & Pro & Ala & Asp & Glu \\
\hline \multicolumn{18}{|l|}{ Feedstuffs (F) } \\
\hline CGM (60\%) & $1.62^{b}$ & $78.06^{\circ}$ & $79.60^{b}$ & $77.74^{c}$ & $77.79^{d}$ & $82.04^{\circ}$ & $73.44^{c}$ & $78.96^{\circ}$ & $79.38^{b}$ & $5.95^{\mathrm{d}}$ & $74.16^{\mathrm{C}}$ & $76.44^{\circ}$ & $74.48^{d}$ & $73.00^{c}$ & $73.66^{\circ}$ & $74.46^{b}$ & $73.03^{d}$ \\
\hline SPC & $95.04^{\mathrm{a}}$ & $97.57^{a}$ & $91.87^{a}$ & $97.35^{\mathrm{a}}$ & $96.88^{a}$ & $98.33^{\mathrm{a}}$ & $96.11^{\mathrm{a}}$ & $93.98^{\mathrm{a}}$ & $94.41^{\mathrm{a}}$ & $95.11^{\mathrm{a}}$ & $98.27^{\mathrm{a}}$ & $93.36^{\mathrm{a}}$ & $98.47^{a}$ & $97.73^{\mathrm{a}}$ & $93.47^{\mathrm{a}}$ & $91.67^{a}$ & $96.84^{a}$ \\
\hline $\mathrm{POM}$ & $85.26^{b}$ & $84.86^{b}$ & $78.90^{\mathrm{b}}$ & $80.33^{c}$ & $84.47^{\circ}$ & $87.01^{b}$ & $83.71^{b}$ & $78.96^{\circ}$ & $79.71^{b}$ & $84.08^{\circ}$ & $83.58^{b}$ & $74.04^{d}$ & $78.42^{\circ}$ & $74.53^{c}$ & $82.01^{b}$ & $62.82^{c}$ & $82.51^{\circ}$ \\
\hline DBP & $94.63^{\mathrm{a}}$ & $96.91^{\mathrm{a}}$ & $78.77^{b}$ & $86.73^{b}$ & $88.73^{b}$ & $87.56^{b}$ & $94.54^{\mathrm{a}}$ & $88.35^{b}$ & $83.98^{b}$ & $91.18^{b}$ & $95.87^{a}$ & $90.42^{b}$ & $91.92^{b}$ & $90.85^{b}$ & $95.37^{\mathrm{a}}$ & $92.40^{\mathrm{a}}$ & $93.21^{b}$ \\
\hline SEM & 1.50 & 0.92 & 1.78 & 1.12 & 1.00 & 0.64 & 1.24 & 0.68 & 1.63 & 0.60 & 1.10 & 0.71 & 0.76 & 1.20 & 1.11 & 0.54 & 0.74 \\
\hline \multicolumn{18}{|c|}{ Enzyme complex (EC) } \\
\hline- & 87.94 & 88.57 & 80.56 & 85.01 & 86.17 & $87.83^{b}$ & 85.83 & $84.24^{b}$ & 82.60 & $85.59^{b}$ & 86.82 & $82.65^{b}$ & $84.89^{b}$ & 82.70 & 85.09 & $9.13^{b}$ & $85.08^{b}$ \\
\hline+ & 90.33 & 90.13 & 84.01 & 86.06 & 87.77 & $89.64^{\mathrm{a}}$ & 88.07 & $85.88^{a}$ & 86.14 & $87.57^{a}$ & 89.12 & $84.47^{\mathrm{a}}$ & $86.75^{\mathrm{a}}$ & 85.36 & 87.17 & $81.55^{a}$ & $87.72^{\mathrm{a}}$ \\
\hline SEM & 1.06 & 0.65 & 1.25 & 0.79 & 0.71 & 0.45 & 0.87 & 0.48 & 1.15 & 0.84 & 0.77 & 0.50 & 0.54 & 0.84 & 0.78 & 0.38 & 0.52 \\
\hline \multicolumn{18}{|l|}{ p-value } \\
\hline F & $<0.001$ & $<0.001$ & 0.002 & $<0.001$ & $<0.001$ & $<0.001$ & $<0.001$ & $<0.001$ & $<0.001$ & $<0.001$ & $<0.001$ & $<0.001$ & $<0.001$ & $<0.001$ & $<0.001$ & $<0.001$ & $<0.001$ \\
\hline EC & 0.1502 & 0.1331 & 0.0888 & 0.381 & 0.15 & 0.0223 & 0.1082 & 0.044 & 0.0624 & 0.0109 & 0.0709 & 0.0337 & 0.0415 & 0.0581 & 0.0971 & 0.0022 & 0.0078 \\
\hline $\mathrm{F} \times \mathrm{EC}$ & 0.5725 & 0.9601 & 0.2853 & 0.9226 & 0.7057 & 0.4947 & 0.9824 & 0.4705 & 0.2612 & 0.585 & 0.7477 & 0.5042 & 0.5221 & 0.8378 & 0.7576 & 0.0067 & 0.3278 \\
\hline
\end{tabular}

M+C, methionine+cystine; CGM, corn gluten meal; SPC, soy protein concentrate; POM, poultry offal meal; DBP, dried bovine plasma; SEM, standard error of the means; (-) without EC; (+) with EC.

${ }^{a-d}$ Means within a column-subgroup with no common superscript letters are significantly different at $p<0.05$ by Scott Knott test. 
Table 4. Standardized ileal digestibility of amino acids (\%) of feedstuffs with or without enzyme complex in seven-day-old broilers

\begin{tabular}{|c|c|c|c|c|c|c|c|c|c|c|c|c|c|c|c|c|}
\hline \multirow{2}{*}{ Items } & \multicolumn{4}{|c|}{ Corn gluten meal $(60 \%)$} & \multicolumn{4}{|c|}{ Soy protein concentrate } & \multicolumn{4}{|c|}{ Poultry offal meal } & \multicolumn{4}{|c|}{ Dried bovine plasma } \\
\hline & - & + & SEM & p-value & - & + & SEM & $\mathrm{p}$-value & - & + & SEM & p-value & - & + & SEM & p-value \\
\hline \multicolumn{17}{|c|}{ Indispensable AA } \\
\hline Met & 77.00 & 79.12 & 1.31 & 0.285 & 96.70 & 98.45 & 1.31 & 0.374 & 84.07 & 85.65 & 1.31 & 0.419 & 96.53 & 97.29 & 1.31 & 0.693 \\
\hline$M+C$ & 77.73 & 77.76 & 1.59 & 0.989 & 96.57 & 98.13 & 1.59 & 0.508 & 80.03 & 80.63 & 1.59 & 0.796 & 85.73 & 87.72 & 1.59 & 0.403 \\
\hline Thr & 77.71 & 77.78 & 1.42 & 0.934 & 95.60 & 98.16 & 1.42 & 0.239 & 82.97 & 85.98 & 1.42 & 0.172 & 88.40 & 89.07 & 1.42 & 0.748 \\
\hline Val & 78.16 & 79.76 & 0.96 & 0.276 & $92.34^{\mathrm{b}}$ & $95.62^{\mathrm{a}}$ & 0.96 & 0.043 & 78.16 & 79.77 & 0.96 & 0.273 & 88.32 & 88.37 & 0.96 & 0.971 \\
\hline Iso & 78.65 & 80.10 & 2.31 & 0.669 & 93.92 & 94.90 & 2.31 & 0.772 & 78.72 & 80.71 & 2.31 & 0.559 & $79.10^{b}$ & $88.86^{a}$ & 2.31 & 0.017 \\
\hline Leu & 75.31 & 76.59 & 0.84 & 0.317 & 94.27 & 95.96 & 0.84 & 0.198 & $82.36^{b}$ & $85.81^{a}$ & 0.84 & 0.0207 & 90.43 & 91.93 & 0.84 & 0.246 \\
\hline Phe & 72.44 & 75.89 & 1.55 & 0.156 & 97.14 & 99.39 & 1.55 & 0.337 & 82.00 & 85.17 & 1.55 & 0.1882 & 95.72 & 96.03 & 1.55 & 0.891 \\
\hline Gly & 75.28 & 77.60 & 1.00 & 0.142 & 93.07 & 93.66 & 1.00 & 0.689 & $72.32^{b}$ & $75.76^{a}$ & 1.00 & 0.042 & 89.95 & 90.89 & 1.00 & 0.529 \\
\hline \multicolumn{17}{|c|}{ Dispensable AA } \\
\hline Ser & 73.24 & 75.72 & 1.08 & 0.143 & 98.31 & 98.63 & 1.08 & 0.842 & 76.71 & 80.14 & 1.08 & 0.055 & 91.32 & 92.51 & 1.08 & 0.459 \\
\hline Pro & 71.45 & 74.56 & 1.69 & 0.231 & 97.34 & 98.12 & 1.69 & 0.753 & 72.72 & 76.35 & 1.69 & 0.1697 & 89.30 & 92.40 & 1.69 & 0.232 \\
\hline
\end{tabular}

SEM, standard error of the means; $A A$, amino acids; $M+C$, methionine+cystine.

$a, b$ Means within a feedstuff group with no common superscript letters are significantly different at $p<0.05$ by Scott Knott test.

Table 5. Standardized ileal digestibility of amino acids (\%) of feedstuffs determined in 21-day-old broilers

\begin{tabular}{|c|c|c|c|c|c|c|c|c|c|c|c|c|c|c|c|c|c|}
\hline Items & Lys & Met & Cys & $M+C$ & Thr & Arg & His & Val & Iso & Leu & Phe & Gly & Ser & Pro & Ala & Asp & Glu \\
\hline \multicolumn{18}{|c|}{ Feedstuffs (F) } \\
\hline CGM $(60 \%)$ & $91.51^{\mathrm{C}}$ & $94.60^{b}$ & 86.71 & $92.77^{\mathrm{a}}$ & $93.60^{a}$ & $94.75^{\mathrm{b}}$ & $89.21^{b}$ & $94.51^{\mathrm{a}}$ & $93.80^{\mathrm{a}}$ & $95.80^{\mathrm{a}}$ & $83.74 b$ & $88.51^{b}$ & $95.14^{\mathrm{a}}$ & $92.57^{\mathrm{a}}$ & $94.86^{\mathrm{a}}$ & $89.88^{b}$ & $94.43^{\mathrm{a}}$ \\
\hline SPC & $94.29^{b}$ & $98.28^{\mathrm{a}}$ & 91.40 & $95.11^{a}$ & $94.71^{a}$ & $97.11^{\mathrm{a}}$ & $94.06^{\mathrm{a}}$ & $93.92^{\mathrm{a}}$ & $93.62^{\mathrm{a}}$ & $93.24^{b}$ & $98.42 \mathrm{a}$ & $91.31^{\mathrm{a}}$ & $96.17^{\mathrm{a}}$ & $95.61^{\mathrm{a}}$ & $91.88^{b}$ & $88.81^{b}$ & $95.11^{\mathrm{a}}$ \\
\hline POM & $81.48^{d}$ & $82.56^{c}$ & 89.41 & $83.27^{b}$ & $82.03^{b}$ & $84.12^{c}$ & $80.57^{\circ}$ & $80.43^{b}$ & $79.77^{b}$ & $81.74^{\circ}$ & $83.73 b$ & $77.93^{\mathrm{c}}$ & $82.56^{b}$ & $75.33^{b}$ & $80.76^{\mathrm{c}}$ & $64.81^{\mathrm{c}}$ & $79.21^{\mathrm{b}}$ \\
\hline DBP & $97.88^{\mathrm{a}}$ & $98.38^{a}$ & 92.91 & $95.89^{\mathrm{a}}$ & $96.54^{\mathrm{a}}$ & $93.70^{b}$ & $96.07^{\mathrm{a}}$ & $92.39^{a}$ & $80.53^{b}$ & $96.89^{\mathrm{a}}$ & 97.61 a & $93.01^{\mathrm{a}}$ & $94.40^{\mathrm{a}}$ & $94.67^{\mathrm{a}}$ & $96.01^{\mathrm{a}}$ & $94.44^{\mathrm{a}}$ & $94.83^{\mathrm{a}}$ \\
\hline SEM & 0.41 & 0.47 & 2.34 & 1.20 & 1.88 & 0.56 & 0.99 & 1.09 & 0.71 & 0.66 & 0.88 & 0.59 & 1.01 & 1.00 & 0.67 & 0.42 & 0.80 \\
\hline \multicolumn{18}{|c|}{ Enzyme complex (EC) } \\
\hline- & 91.09 & 93.00 & 88.13 & 91.26 & 91.65 & 92.08 & 89.49 & 89.79 & $86.05^{b}$ & 91.36 & $89.45^{b}$ & $86.91^{b}$ & 91.17 & 88.58 & 90.18 & 84.27 & 90.49 \\
\hline+ & 91.48 & 93.91 & 92.08 & 92.26 & 91.80 & 92.76 & 90.46 & 90.83 & $87.80^{\mathrm{a}}$ & 92.47 & $92.30^{a}$ & $88.46^{\mathrm{a}}$ & 92.97 & 90.51 & 91.57 & 84.70 & 91.30 \\
\hline SEM & 0.29 & 0.33 & 1.65 & 0.85 & 1.33 & 0.39 & 0.70 & 0.77 & 0.50 & 0.46 & 0.62 & 0.42 & 0.71 & 0.70 & 0.47 & 0.29 & 0.57 \\
\hline \multicolumn{18}{|l|}{$\mathrm{p}$-value } \\
\hline F & $<0.001$ & $<0.001$ & 0.3366 & $<0.001$ & 0.0024 & $<0.001$ & $<0.001$ & $<0.001$ & $<0.001$ & $<0.001$ & $<0.001$ & $<0.001$ & $<0.001$ & $<0.001$ & $<0.001$ & $<0.001$ & $<0.001$ \\
\hline $\mathrm{EC}$ & 0.3668 & 0.092 & 0.1301 & 0.432 & 0.9386 & 0.2617 & 0.3573 & 0.3713 & 0.04 & 0.134 & 0.0121 & 0.0311 & 0.112 & 0.0903 & 0.0733 & 0.3455 & 0.3473 \\
\hline$F \times E C$ & 0.5727 & 0.6154 & 0.7188 & 0.9688 & 0.9984 & 0.5755 & 0.8045 & 0.8951 & 0.1352 & 0.6389 & 0.0743 & 0.9904 & 0.5991 & 0.7419 & 0.9579 & 0.1436 & 0.5604 \\
\hline
\end{tabular}

$\mathrm{M}+\mathrm{C}$, methionine+cystine;CGM, corn gluten meal; SPC, soy protein concentrate; POM, poultry offal meal; DBP, dried bovine plasma; SEM, standard error of the means; (-) without EC; (+) with EC.

${ }^{a-d}$ Means within a column-subgroup with no common superscript letters are significantly different at $p<0.05$ by Scott Knott test.

\section{DISCUSSION}

The aim of this study was to evaluate the effect of EC on the SID of AA of four protein sources in pre-starter and starter broilers' diets. Knowledge of the AA digestibility of feed ingredients is of great importance, especially when aiming to use an unconventional feedstuff in broiler diets. In the present study, it was verified that in the pre-starter phase the SID of arginine, branched chain-aminoacids, glycine, serine, aspartate, and glutamic acid was increased in EC-supplemented diets. In contrast, at the starter phase, only the SID of isoleucine, phenylalanine and glycine increased with EC addition to the diet. This improvement occurred independently of the feedstuff studied. In addition, the experiments showed that the SID of AA is different according to the feedstuffs.

On average, SPC showed the highest SID of all the feedstuffs tested in this study, which makes it an excellent protein source for birds in the pre-starter phase. The high digestibility of AA in pre-starter diets is important, since it has been related that dietary AA affects the body weight gain, the growth rate, the feed conversion ratio, the internal organ development of broilers [12] and the improved function of the gastrointestinal tract of broilers [13]. Some factors influence the AA digestibility in broilers. [17] verified that the defatting process of insect meal increased glutamic acid, proline, and serine digestibility. Yaghobfar [1] verified that the AA digestibility 
Table 6. Standardized ileal digestibility of amino acids (\%) of feedstuffs with or without enzyme complex in 21-day-old broilers

\begin{tabular}{|c|c|c|c|c|c|c|c|c|c|c|c|c|c|c|c|c|}
\hline \multirow{2}{*}{ Items } & \multicolumn{4}{|c|}{ Corn gluten meal $(60 \%)$} & \multicolumn{4}{|c|}{ Soy protein concentrate } & \multicolumn{4}{|c|}{ Poultry offal meal } & \multicolumn{4}{|c|}{ Dried bovine plasma } \\
\hline & - & + & SEM & p-value & - & + & SEM & p-value & - & + & SEM & p-value & - & + & SEM & p-value \\
\hline \multicolumn{17}{|c|}{ Indispensable AA } \\
\hline Lys & 91.20 & 91.82 & 0.58 & 0.471 & 94.11 & 94.48 & 0.58 & 0.664 & 80.93 & 82.04 & 0.58 & 0.211 & 98.16 & 97.62 & 0.58 & 0.532 \\
\hline Met & 93.68 & 95.53 & 0.67 & 0.087 & 97.95 & 98.62 & 0.67 & 0.501 & 82.03 & 83.10 & 0.67 & 0.293 & 98.36 & 98.41 & 0.67 & 0.959 \\
\hline$M+C$ & 91.81 & 93.73 & 1.70 & 0.484 & 94.61 & 95.62 & 1.70 & 0.686 & 82.89 & 83.66 & 1.70 & 0.757 & 95.75 & 96.04 & 1.70 & 0.907 \\
\hline Thr & 93.24 & 93.97 & 2.66 & 0.851 & 94.76 & 94.66 & 2.66 & 0.979 & 82.06 & 82.02 & 2.66 & 0.990 & 96.54 & 96.56 & 2.66 & 0.996 \\
\hline $\operatorname{Arg}$ & 94.27 & 95.24 & 0.79 & 0.411 & 97.19 & 97.04 & 0.79 & 0.893 & 83.19 & 85.06 & 0.79 & 0.132 & 93.70 & 93.72 & 0.79 & 0.989 \\
\hline His & 87.96 & 90.47 & 1.40 & 0.243 & 94.10 & 94.03 & 1.40 & 0.974 & 80.00 & 81.16 & 1.40 & 0.577 & 95.93 & 96.23 & 1.40 & 0.885 \\
\hline Val & 93.32 & 95.72 & 1.54 & 0.304 & 93.50 & 94.35 & 1.54 & 0.707 & 80.04 & 80.83 & 1.54 & 0.725 & 92.35 & 92.44 & 1.54 & 0.966 \\
\hline Iso & 92.21 & 95.39 & 1.01 & 0.057 & 94.13 & 93.12 & 1.01 & 0.503 & 79.33 & 80.21 & 1.01 & 0.556 & $78.55^{\mathrm{b}}$ & $82.52^{\mathrm{a}}$ & 1.01 & 0.024 \\
\hline Leu & 94.86 & 96.75 & 0.93 & 0.192 & 92.68 & 93.81 & 0.93 & 0.419 & 80.87 & 82.62 & 0.93 & 0.224 & 97.07 & 96.73 & 0.93 & 0.804 \\
\hline Phe & $80.90^{b}$ & $86.57^{\mathrm{a}}$ & 1.25 & 0.012 & 98.33 & 98.53 & 1.25 & 0.914 & $80.90^{\mathrm{b}}$ & $86.57^{\mathrm{a}}$ & 1.25 & 0.012 & 97.48 & 97.75 & 1.25 & 0.882 \\
\hline Gly & 87.83 & 89.19 & 0.84 & 0.286 & 90.55 & 92.07 & 0.84 & 0.237 & 77.00 & 78.87 & 0.84 & 0.154 & 92.28 & 93.74 & 0.84 & 0.255 \\
\hline \multicolumn{17}{|c|}{ Dispensable AA } \\
\hline Cys & 82.64 & 90.80 & 3.31 & 0.119 & 90.75 & 92.06 & 3.31 & 0.786 & 87.11 & 91.73 & 3.31 & 0.352 & 92.06 & 93.77 & 3.31 & 0.724 \\
\hline Ala & 94.20 & 95.53 & 0.95 & 0.351 & 91.29 & 92.48 & 0.95 & 0.403 & 79.77 & 81.77 & 0.95 & 0.176 & 95.50 & 96.53 & 0.95 & 0.465 \\
\hline Asp & 89.11 & 90.66 & 0.59 & 0.104 & 89.48 & 88.15 & 0.59 & 0.154 & 64.72 & 64.91 & 0.59 & 0.827 & 93.80 & 95.09 & 0.59 & 0.167 \\
\hline Glu & 93.67 & 95.20 & 1.14 & 0.370 & 95.53 & 94.71 & 1.14 & 0.622 & 78.07 & 80.36 & 1.14 & 0.193 & 94.73 & 94.95 & 1.14 & 0.892 \\
\hline Ser & 94.92 & 95.38 & 1.43 & 0.825 & 96.00 & 96.35 & 1.43 & 0.866 & 80.79 & 84.35 & 1.43 & 0.116 & 92.98 & 95.84 & 1.43 & 0.195 \\
\hline Pro & 91.79 & 93.36 & 1.41 & 0.457 & 95.45 & 95.77 & 1.41 & 0.877 & 73.65 & 77.03 & 1.41 & 0.130 & 93.45 & 95.91 & 1.41 & 0.254 \\
\hline
\end{tabular}

SEM, standard error of the means; $A A$, amino acids; $M+C$, methionine+cystine.

${ }^{a, b}$ Means within a feedstuff group with no common superscript letters are significantly different at $p<0.05$ by Scott Knott test.

of soybean, sunflower and canola meals was lower in broilers than in intact and caecectomized cockerels, indicating that age affects the use of AA by broilers.

The SID of lysine, methionine, histidine, alanine, and aspartate were similar between the CPS and the DPB, indicating that DPB is a great alternative animal byproduct to use in pre-starter broilers' diets. Furthermore, the SID of isoleucine of DBP increased with EC inclusion. Lysine, methionine, and threonine are the first three limiting AA for broilers fed a corn-soybean meal diet and are present in great quantities in SPC and DPB. Therefore, [18] related that the spray-dried

Table 7. Standardized digestible amino acid contents of feedstuffs (\%) (as-fed basis) ${ }^{1)}$

\begin{tabular}{lcccc}
\hline Items & CGM & SPC & POM & DBP \\
\hline Dry matter & 91.62 & 94.03 & 95.01 & 92.08 \\
Crude protein & 62.09 & 62.36 & 63.73 & 70.30 \\
Lysine & 0.92 & 3.43 & 3.31 & 5.95 \\
Methionine & 1.35 & 0.77 & 1.15 & 0.66 \\
Methionine+cystine & 2.33 & 1.49 & 1.54 & 3.26 \\
Threonine & 1.94 & 2.36 & 1.93 & 4.28 \\
Arginine & 1.79 & 4.24 & 3.83 & 3.33 \\
Histidine & 1.21 & 1.47 & 0.93 & 2.35 \\
Valine & 2.57 & 2.46 & 2.32 & 4.40 \\
Isoleucine & 2.26 & 2.44 & 1.94 & 1.99 \\
Leucine & 9.31 & 4.31 & 3.63 & 6.20 \\
Phenylalanine & 3.51 & 2.85 & 2.11 & 3.71 \\
Cystine & 1.02 & 0.79 & 0.46 & 1.77 \\
\hline
\end{tabular}

1) Aminogram developed by Evonik Industries AG Feed Additives/Animal Nutrition Services.

CGM, corn gluten meal; SPC, soy protein concentrate; POM, poultry offal meal; DBP, dried bovine plasma; plasma improves early intestinal health and supports an efficient immune system response both locally at the intestine and systemically, thereby benefiting growth, feed efficiency,

\section{Pre-starter phase}

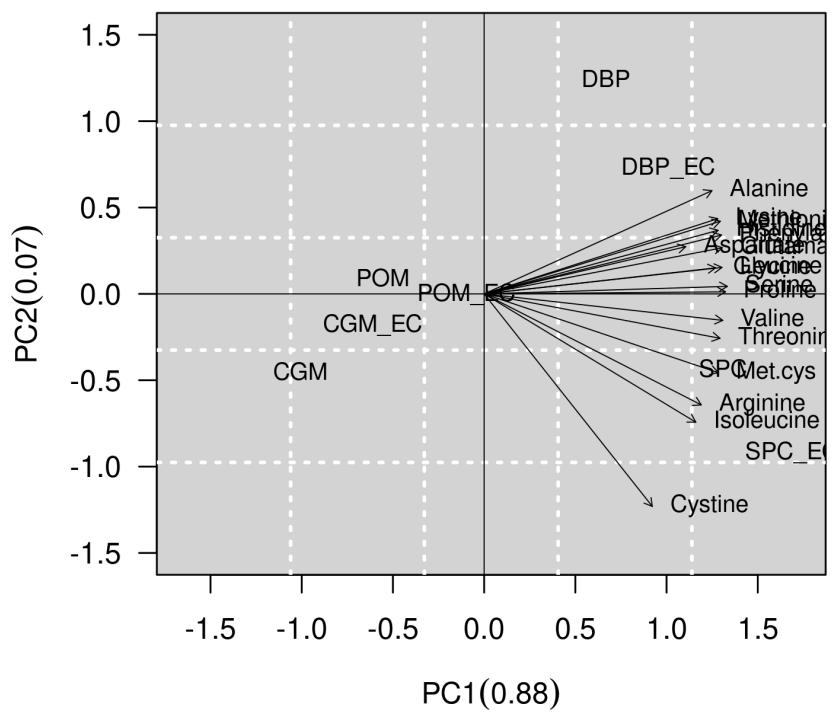

Figure 1. 2D plot generated by principal component analysis. The graph shows a separation between the feedstuffs with or without the enzyme complex and their relationship to the standardized ileal digestibility (SID) of amino acids (AA), based on multivariate analysis in pre-starter phase. CGM, corn gluten meal; CGM_EC, corn gluten meal with enzyme complex; SPC, soy protein concentrate; SPC_EC, soy protein concentrate with enzyme complex; POM, poultry offal meal; POM_EC, poultry offal meal with enzyme complex; DBP, dried bovine plasma; DBP_EC, dried bovine plasma with enzyme complex. 


\section{Starter phase}

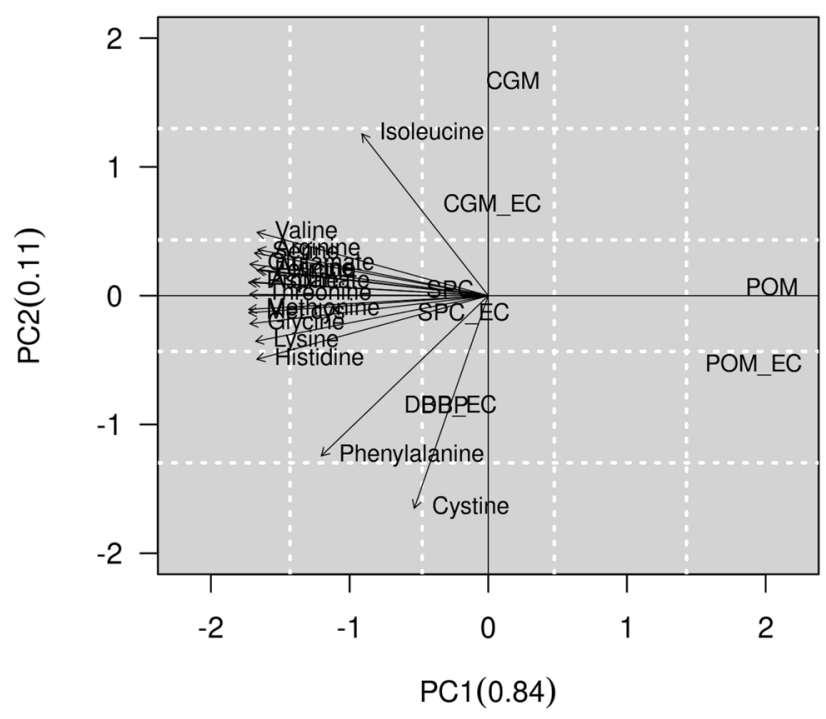

Figure 2. 2D plot generated by principal component analysis. The graph shows a separation between the feedstuffs with or without the enzyme complex and their relationship to standardized ileal digestibility (SID) of amino acids (AA), based on multivariate analysis in starter phase. CGM, corn gluten meal; CGM_EC, corn gluten meal with enzyme complex; SPC, soy protein concentrate; SPC_EC, soy protein concentrate with enzyme complex; POM, poultry offal meal; POM_EC, poultry offal meal with enzyme complex; DBP, dried bovine plasma; DBP_EC, dried bovine plasma with enzyme complex.

and survival of broilers.

The CGM presented the lowest SID of indispensable AA in pre-stater diets. However, the addition of EC was able to increase the SID of arginine and glutamic acid in the broilers fed the diet containing CGM. The CGM showed the lowest digestibility coefficients among the plant-based products, which may be due to its high fibre content, which reduces the AA digestibility.

At the pre-starter phase, the SID of arginine, branched chain-aminoacids, glycine, serine, aspartate, and glutamic acid increased in EC-supplemented diets. These AA are classified as polar and non-polar, indicating that the EC did not improve the digestibility of a specific group of AAs. The SID of these AA was increased up to $2.41 \%$ in mean, with the EC inclusion. The results agree with [6], verifying that the exogenous protease addition resulted in an increase in ileal AA digestibility of over $2.5 \%$. There are many mechanisms by which the enzyme improves the SID of AA. The EC reduces the viscosity of digesta [19-21], increases digesta retention time in the ileum [22], facilitating the digestion of nutrients by the digestive enzymes. Furthermore, it has been shown that the phytase plus xylanase combination increased sodium digestibility [22]. Since AA absorption is sodium-dependent, the increase of sodium digestibility could result in an enhanced SID of AA. In addition to these factors, the addition of exog- enous protease to the diet increases the jejunal expression of genes responsible for peptide transport [6], resulting in better utilization of some AA. Cowieson et al [23] reported that exogenous protease may influence digestive dynamics through altered secretion of intestinal mucin, improved tight junction integrity and changed emphasis on AA transport.

The SID of AA within each feedstuff with or without EC was studied in the pre-starter phase. In the SPC, the SID were significantly higher for valine and cystine in the EC-supplemented diets. It was verified that all the AA present SID up to $90 \%$ in SPC. The inherent high digestibility of AA of SPC could contribute to a lack of effect of EC in enhancing the SID of other AA.

The SID of leucine, glycine and aspartate on POM was improved when the EC was used. The improvement of glycine digestibility in the pre-starter diet is important. Dietary glycine may need to be considered as a limiting nutrient in early nutrition, especially if the $\mathrm{CP}$ is low, and only vegetable ingredients are being used [24].

At the starter phase, it was verified that the SID of some AA of SPC, DBP, and CGM was similar, indicating better utilization of AAs of alternative feedstuffs with the increase of age. In this context, it is important to evaluate differences in AA digestibility in broiler chicks in the first week of life, given the limitations that occur in the digestive processes that affect nutritional utilization at that stage $[25,26]$. Because AA digestibility in birds is determined in the third week of life, differences in physiological maturity, especially in terms of intestinal functions and enzyme action, are greater than in the pre-starter phase, which can affect nutrient utilization efficiency and body development in these animals.

At the starter phase, only the SID of isoleucine, phenylalanine and glycine increased with EC addition in the diet (average of increase of $2.33 \%$ ). At the starter phase, the digestive system of the broiler is completely developed, and age could influence the SID of AA. Szczurek et al [27] verified that the SID value of AA in wheat was not influenced by the age of broilers, but the SID of most AA in triticale, and all the AA in barley, were higher in 28-day-old chickens compared with 14-day-olds. The results suggested that the SID coefficients of AA are influenced by the age of birds in a feedstuff-dependent way. In addition to the age of birds, other factors can affect the efficacy of exogenous enzymes and the AA digestibility. The dietary levels of available phosphorus and calcium can influence the efficacy of the combination of a multi-carbohydrase and phytase complex, on the digestibility of AAs of broilers [28].

The standardized AA contents of the feedstuffs were calculated from the total AA content and the SID. Although the feedstuffs studied are protein sources, the contents of AA in each presented great variation. The digestible AA content of SPC was, on average, lower than those observed by [29], 
probably due to the lower protein levels found in this feedstuff in the present experiment. In fact, differences in nutritive value do exist between SBM from different origins in terms of nutrient contents, apparent metabolizable energy, and digestible AA [2].

The POM showed the greatest variation in digestible AA content between the feedstuffs of animal origin. This result can be attributed to the broad variations in its composition, which also explains the divergent AA compositions between different studies. The observed differences in AA content can be attributed to a lack of standardization in the processing of the evaluated feedstuffs. The processing of a feedstuff greatly influences the digestibility of AA. Overprocessing, for instance, can lead to a deficiency in sulfur-containing AAs, especially cystine, which is converted to lanthionine, which in turn has low nutritional value. On the other hand, insufficient processing may result in incomplete hydrolysis, which translates into lower nutrient digestibility [30]. The reduced digestibility of lysine may be attributed to the formation of Maillard reaction products during thermal processing.

In summary, we verified that the EC effectively improved the SID of AA of feedstuffs, resulting in the better utilization of some AA by birds. The addition of EC increased AA digestibility by an average of $2.41 \%$ and $2.33 \%$, respectively, at the pre-starter and starter phases.

\section{CONCLUSION}

The addition of an EC to broiler pre-starter and starter diets is efficient in increasing the SID of AA on SPC, POM and DBP.

\section{CONFLICT OF INTEREST}

We certify that there is no conflict of interest with any financial organization regarding the material discussed in the manuscript.

\section{FUNDING}

The authors would like to thank the Conselho Nacional de Desenvolvimento Científico e Tecnológico (CNPq) for the research funding (Process number 156224/2010-0), the São Salvador Alimentos, the Evonik and the Cargill.

\section{REFERENCES}

1. Yaghobfar A. Effects of bioassay and age on amino acid digestibility and metabolizable energy of soybean, sunflower and canola meals. Iranian J Appl Anim Sci 2013;3:249-61.

2. Ravindran V, Adbollahi MR, Bootwalla SM. Nutrient analysis, metabolizable energy, and digestible amino acids of soybean meals of different origins for broilers. Poult Sci 2014;93:2567-
77. https://doi.org/10.3382/ps.2014-04068

3. Smit MN, Ketelaar RF, He L, Beltranena E. Ileal digestibility of energy and amino acids in three faba bean cultivars (Vicia faba L.) planted and harvested early or late in broiler chickens. Poult Sci 2021;100:101332. https://doi.org/10.1016/j.psj.2021. 101332

4. Alshelmani MI, Loh TC, Foo HL, Sazili AQ, Lau WH. Effect of solid state fermentation on nutrient content and ileal amino acids digestibility of palm kernel cake in broiler chickens. Indian J Anim Sci 2017;87:1135-40.

5. Romero LF, Parsons CM, Utterback PL, Plumstead PW, Ravindran V. Comparative effects of dietary carbohydrases without or with protease on the ileal digestibility of energy and amino acids and AMEn in young broilers. Anim Feed Sci Technol 2013;181:35-44. https://doi.org/10.1016/j.ani feedsci.2013.02.001

6. Cowieson AJ, Toghyani M, Kheravii SK, WuS B, Romero LF, Choct M. A mono-component microbial protease improves performance, net energy, and digestibility of amino acids and starch, and upregulates jejunal expression of genes responsible for peptide transport in broilers fed corn/wheatbased diets supplemented with xylanase and phytase. Poult Sci 2019;98:1321-32. https://doi.org/10.3382/ps/pey456

7. Olukomaiya OO, Pan L, Zhang D, Mereddy R, Sultanbawa Y, Li X. Effect of solid-state fermented and enzyme-supplemented lupins on performance and ileal amino acid digestibility in broiler chickens. Anim Prod Sci 2021;61:1449-59. https://doi. org/10.1071/AN21038

8. Andrade TS, Nunes RV, Wachholz L, da Silva IM, de Freitas DM. The effect of exogenous enzymes on the performance and digestibility of nutrients in broiler. Semin Cienc Agrar 2018;39:711-8. https://doi.org/10.5433/16790359.2018v39n 2p711

9. Bryden WL, Li X. Amino acid digestibility and poultry feed formulation: expression, limitations and application. R Bras Zootec 2010;39:279-87. https://doi.org/10.1590/S1516-3598 2010001300031

10.Dosković V, Bogosavljević-Bosković S, Pavlovski Z, et al. Enzymes in broiler diets with special reference to protease. World Poult Sci J 2013;69:343-60. https://doi.org/10.1017/ S0043933913000342

11.Jlali M, Cozannet P, Alleno C, Preynat A. Evaluation of a multicarbohydrase and phytase complex in reduced energy, amino acids, available phosphorus and calcium diets fed to broilers. Livest Sci 2020;241:104227. https://doi.org/10.1016/ j.livsci.2020.104227

12.Zhang B, Zhang X, Schilling MW, Tabler GT, Peebles ED, Zhai W. Effects of broiler genetic strain and dietary amino acid reduction on (part I) growth performance and internal organ development. Poult Sci 2020;99:3266-79. https://doi. org/10.1016/j.psj.2020.03.024

13. Bortoluzzi C, Fernandes JIM, Doranalli K, Applegate TJ. Effects 
of dietary amino acids in ameliorating intestinal function during enteric challenges in broiler chickens. Anim Feed Sci Technol 2019;262:114383. https://doi.org/10.1016/j.ani feedsci.2019.114383

14. Gallardo C, Dadalt JC, Kiarie E, Neto MT. Effects of multicarbohydrase and phytase on standardized ileal digestibility of amino acids and apparent metabolizable energy in canola meal fed to broiler chicks. Poult Sci 2017;96:3305-13. https:// doi.org/10.3382/ps/pex141

15. Sakomura NK, Rostagno HS. Research methods in monogastric nutrition. 2nd ed. Jaboticabal, SP, Brazil: Funep; 2016.

16.Silva DJ, Queiroz AC. Food analysis (chemical and biological methods). 3rd ed. Viçosa, MG, Brazil: Editora da Universidade Federal de Viçosa; 2002.

17. Schiavone A, De Marco M, Martínez S, et al. Nutritional value of a partially defatted and a highly defatted black soldier fly larvae (Hermetia illucens L.) meal for broiler chickens: apparent nutrient digestibility, apparent metabolizable energy and apparent ileal amino acid digestibility. J Anim Sci Biotechnol 2017;8:51. https://doi.org/10.1186/s40104-017-0181-5

18.Campbell JM, Crenshaw JD, González-Esquerra R, Polo J. Impact of spray-dried plasma on intestinal health and broiler performance. Microorganisms 2019;7:219. https://doi.org/ 10.3390/microorganisms7080219

19. Passos AA, Par I, Ferket P, Von Heimendahl E, Kim SW. Effect of dietary supplementation of xylanase on apparent ileal digestibility of nutrients, viscosity of digesta, and intestinal morphology of growing pigs fed corn and soybean meal based diet. Anim Nutr 2015;1:19-23. https://doi.org/10.1016/j.aninu. 2015.02.006

20.Munyaka PM, Nandha NK, Kiarie E, Nyachoti CM, Khafipour E. Impact of combined $\beta$-glucanase and xylanase enzymes on growth performance, nutrients utilization and gut microbiota in broiler chickens fed corn or wheat-based diets. Poult Sci 2016;95:528-40. https://doi.org/10.3382/ps/pev333

21.Moftakharzadeh SA, Moravej H, Shivazad M. Effect of using the matrix values for NSP-degrading enzymes on performance, water intake, litter moisture and jejunal digesta viscosity of broilers fed barley-based diet. Acta Sci Anim Sci 2017;39:65-72. https://doi.org/10.4025/actascianimsci.v39i1. 33070
22. Moss AF, Chrystal PV, Dersjant-Li Y, Selle PH, Liu SY. Responses in digestibilities of macro-minerals, trace minerals and amino acids generated by exogenous phytase and xylanase in canola meal diets offered to broiler chickens. Anim Feed Sci Technol 2018;240:22-30. https://doi.org/10.1016/j.ani feedsci.2018.03.011

23. Cowieson AJ, Lu H, Ajuwon KM, Knap I, Adeola O. Interactive effects of dietary protein source and exogenous protease on growth performance, immune competence and jejunal health of broiler chickens. Anim Prod Sci 2016;57:252-61. https://doi.org/10.1071/AN15523

24. Corzo A, Kidd MT, Burnham DJ, Kerr BJ. Dietary glycine needs of broiler chicks. Poult Sci 2004;83:1382-4. https:// doi.org/10.1093/ps/83.8.1382

25. Batal AB, Parsons CM. Utilization of different soy products as affected by age in chicks. Poult Sci 2003;82:454-62. https:// doi.org/10.1093/ps/82.3.454

26.Stringhini JH, Andrade ML, Xavier SAG, Andrade MA, Minafra CS, Café MB. Protein and amino acid supplementation levels for broilers in pre-starter ration. Int J Poult Sci 2009;8:946-51. https://doi.org/10.3923/ijps.2009.946.951

27.Szczurek W, Szymczyk B, Arczewska-Włosek A, Świątkiewicz S. Apparent and standardised ileal digestibility of amino acids in wheat, triticale and barley for broiler chickens at two different ages. Br Poult Sci 2020;61:63-9. https://doi.org/ 10.1080/00071668.2019.1673317

28.Jlali M, Cozannet P, Moore D, Preynat A. Investigating the effect of available phosphorus and calcium level on the potential of a multi-carbohydrase and phytase complex on growth performance, amino acids and phosphorus digestibility in broilers from 1 to 21 days of age. Anim Feed Sci Technol 2021;276:114927. https://doi.org/10.1016/j.anifeedsci.2021. 114927

29. Rostagno HS, Albino LFT, Hannas MI, et al. Brazilian tables for poultry and swine: food composition and nutritional requirements. 4 th ed. Viçosa, MG: Editora UFV; 2017.

30.Eyng C, Nunes RV, Rostagno HS, Albino LFT, Nunes CGV, Bruno LDG. Chemical composition, energetic values and real digestible amino acid of different viscera meals for poultry. R Bras Zootec 2010;39:779-86. https://doi.org/10.1590/S151635982010000400012 